\title{
Milk Transcriptome
}

\author{
Minja Zorc, Jernej Ogorevc and Peter Dovč* \\ Department of Animal Science, University of Ljubljana, Slovenia, Europe
}

Submission: December 01, 2018; Published: December 11, 2018

*Corresponding author: Peter Dovč, Department of Animal Science, Biotechnical Faculty, University of Ljubljana, Groblje 3, SI-1230 Domžale, Slovenia, Europe

\section{Abstract}

Milk transcriptome sequencing is a promising technology, which closes the gap between high density genotyping and phenotyping data. In addition to the power to discover a large number of genetic polymorphisms, the sequencing of the transcriptome can offer important information on transcriptional activity of mammary gland cells which cannot be collected at DNA level. The most important findings in this context are related to posttranscriptional modifications in the mammary gland and detection of transcripts representing non-protein coding regions of the genome. Among them are most prominent regions coding different types of RNA (lncRNA, miRNA, siRNA, piRNA, snoRNA) which are involved in complex regulatory networks. Transcriptome sequencing has also potential to identify novel causative SNPs associated with complex phenotypic traits. These novel informative SNPs are good candidates for marker assisted selection in dairy herds.

Keywords: Lactation; Mammary gland; Milk; RNA-seq; Transcriptome

Abbreviations: FAANG: Functional Annotation of Animal Genomes; EGF: Epidermal Growth Factor; QTL: Quantitative Trait Loci; STAT5A: Signal Transducer and Activator of Transcription 5A; RNASEH2B: Ribonuclease H2 Subunit B; PROP1: Prophet of Pit 1; QC: Quality Control; SNP: Single Nucleotide Polymorphisms; GEO: Gene Expression Omnibus; SRA: Sequence Read Archive; MECs: Mammary Epithelial Cells; PMN: Polymorphonuclear; PPAR: Peroxisome Proliferator-Activated Receptor;

\section{Introduction}

Understanding the relationship between genetic variability and phenotypic variation in domestic animals is one of the central problems in animal breeding. In the past, selection in farm animals was based on reliability of pedigree data and more or less precise recording of phenotypic data describing economically important traits. With the development of molecular genetics, different types of molecular data, characterizing animal genome were used to study association between genotype and phenotypic traits.

The early studies were based on relatively small sets of data, including mainly polymorphisms located within selected DNA regions, coding for proteins involved in shaping of phenotypic traits [1]. Later, some other genetic markers (microsatellites, single nucleotide polymorphisms - SNP) were used, allowing more precise mapping of candidate regions affecting complex quantitative traits. In spite of the fact that the number of markers was growing fast, the intervals between markers were still relatively long and there was always the risk, that the identified SNP was not a causal one, but only linked to the causal mutation, which remained hidden in the region not covered by genetic markers [2].

This problem could be solved using whole genome sequences for genotyping instead of several hundreds of thousands of SNP markers. However, due to the high number of sequence differences between individuals and technical problems related with genome annotation, sequencing errors and genomic structural variation it is often difficult to identify causal mutations, which have significant effect on complex phenotypic traits, from whole genome sequencing data [2]. Due to the fact that in each tissue/cell type only a portion of coding regions of the genome is transcriptionally active, the number of potential causal mutations for a certain phenotypic trait is considerably reduced. Therefore, sequencing of RNA from tissues which are involved in expression of a certain phenotypic trait is a good possibility to focus genomic analysis only on regions which are transcriptionally active in the tissue/ cells associated with phenotypic trait of interest [3]. Analysis of tissue specific transcriptome enables detection of genetic variation at posttranscriptional level, which cannot be detected at the DNA level (e.g. alternative splicing, differential allelic expression).

Compared with whole genome sequencing, sequencing of transcriptome offers a cheaper alternative for identification of genetic variants associated with phenotypic variation. RNA sequencing also offers an insight into identification of new regulatory pathways affecting expression of complex traits [4]. In addition to detection of genetic variants within coding regions for proteins involved in shaping quantitative traits, provides RNA sequencing valuable information about genetic variants in non protein coding genomic regions (IncRNA, miRNA, siRNA, piRNA, snoRNA). It has been estimated, that functional noncoding elements represent up to $98 \%$ of human transcriptome 
[5]. Identification of these functional elements in animal genomes is an important task of international consortium for Functional Annotation of Animal Genomes (FAANG) [6].

\section{Milk Transcriptome}

Transcriptomic studies in the mammary gland have been performed using mainly two technologies: expression microarrays and RNA-Seq. Both technologies have been widely used in lactation research, however due to the rapid development of the next generation sequencing technology, RNA-Seq is becoming the most frequently used approach for transcriptomic analyses in mammary gland [3]. Different platforms using next generation sequencing methodology enabled collection of large amount of transcriptomic data from different species, stages of lactation and different production levels [7].

Biological material used for RNA isolation plays an important role in transcriptome analysis. For analysis of mammary gland transcriptome, material as biopsies of mammary gland tissue, milk somatic cells, laser dissections of frozen mammary gland tissue, milk fat globules and antibody captured milk mammary epithelial cells have been used. Especially the last method allows precise separation of different cell sub-types and development of for certain cell types specific transcriptomic profiles [8]. Canovas et al. (2010) compared the transcriptomic profiles from different sources and concluded that milk somatic cells and milk fat globules represent a reliable source for RNA isolation for milk transcriptomic studies.

Transcriptomic studies have revealed more than 33000 SNPs associated with lactation, which can be used as genetic markers for marker assisted selection in dairy cows [9]. Differentially expressed genes between high and low producing animals deserve special attention. These genes reflect the role of a number of specific biologic processes involved in lactation [10]. The other group of promising candidate genes are genes that are expressed in the mammary gland and are located within the quantitative trait loci (QTL) related to lactation traits. This strategy can help to identify novel candidate genes associated with lactation traits.

Transcriptomic analysis in different stages of lactation identified some important biological pathways associated with paired-end read format. the development of mammary gland and lactation. During the pregnancy, genes involved in development of morphogenesis of mammary ducts and differentiation of the mammary alveoli play an important role [11]. For the initiation of lactation is characteristic up-regulation of genes involved in milk synthesis together with the inhibition of genes related to cell proliferation. During the very early lactation, some immune- and development-related miRNAs are highly expressed [12]. Genes involved in synthesis of milk constituents and milk synthesis-related pathways are constantly expressed during lactation [13]. Finally, during the involution the most prominent groups of expressed genes are immune and antioxidant-related genes, whereas genes related to milk synthesis are down regulated [14]. Genomic and transcriptomic studies revealed several loci associated with milk production traits. So were gene polymorphisms in epidermal growth factor (EGF) and signal transducer and activator of transcription 5A (STAT5A), as well as missense mutation of prophet of Pit 1 (PROP1) and deletion of Ribonuclease H2 Subunit B (RNASEH2B) associated with milk production [15].

\section{Bioinformatics Approach}

The transcriptome profiling is typically performed using expression microarrays or RNA-Seq methodology. Both methods produce extensive data and require complex bioinformatics analysis. Microarrays are effective in expression profiling of known genes and transcripts, and were the method of choice until the late 2000s [16]. RNA-Seq is not dependent on existing genomic data, and offers more comprehensive investigation of the transcriptome. With its advantages, it has slowly replaced microarray-based transcriptome analyses.

Transcriptome of human milk has been analysed using expression microarrays [17]. However, RNA-Seq is now predominant method used in milk transcriptome profiling. Milk transcriptome sequencing data sets generated from different studies on humans, mouse, livestock and other mammals, such as rhesus macaque, and Tasmanian devil were deposited in NCBI's Gene Expression Omnibus (GEO) database, Sequence Read Archive (SRA) or BioProject (Table 1). Sequencing of milk transcriptomes in some studies was performed on Illumina Genome Analyzer IIx, but in most of the studies on Illumina HiSeq2000 in a single or

Table 1: Milk transcriptome sequencing data.

\begin{tabular}{|c|c|c|c|c|}
\hline Study & Species & Sequencing Technology & Accession Number & Reference \\
\hline $\begin{array}{c}\text { Expression profiling of genes expressed in } \\
\text { milk somatic cells of transition (day 15), } \\
\text { peak (day 90) and late (day 250) lactation } \\
\text { in Holstein cows. }\end{array}$ & $\begin{array}{c}\text { Cow (Bos taurus) } \\
\text { Holstein }\end{array}$ & $\begin{array}{c}\text { Illumina Genome Analyzer (GAII), } \\
36-40 \text { bp short sequence reads }\end{array}$ & $\begin{array}{c}\text { Wickramasinghe } \\
\text { Saumya, et al. [24] }\end{array}$ \\
\hline $\begin{array}{c}\text { MicroRNA expression profiles of bovine } \\
\text { milk exosomes in response to Staphylococ- } \\
\text { cus aureus infection. }\end{array}$ & $\begin{array}{c}\text { Cow (Bos taurus) } \\
\text { Holstein }\end{array}$ & $\begin{array}{c}\text { Illumina Genome Analyzer II, 40 bp } \\
\text { single-end sequencing }\end{array}$ & GSE55144 (GE0) & Sun, et al. [39] \\
\hline $\begin{array}{c}\text { Differential expression of genes in milk fat } \\
\text { globules at day 10 and day 70 after calving } \\
\text { between two groups of cows with ex- } \\
\text { tremely high and low 305-day milk yield, } \\
\text { milk fat yield and milk protein yield. }\end{array}$ & $\begin{array}{c}\text { Cow (Bos taurus) } \\
\text { Chinese Holstein }\end{array}$ & Illumina HiSeq 2000, paired-end & SRP064718 (SRA) & Yang, et al. [41] \\
\hline
\end{tabular}


Journal of Dairy \& Veterinary Sciences

\begin{tabular}{|c|c|c|c|c|}
\hline $\begin{array}{l}\text { Differential expression of genes in goat } \\
\text { colostrum and mature milk. }\end{array}$ & $\begin{array}{l}\text { Goat (Capra } \\
\text { hircus) }\end{array}$ & $\begin{array}{l}\text { Genome Analyzer IIx, } 79 \text { bp paired- } \\
\text { end sequence reads }\end{array}$ & SRP057582 (SRA) & Crisa, et al. [34] \\
\hline $\begin{array}{l}\text { Transcriptome profile during three stages } \\
\text { of lactation: colostral, transitional, and } \\
\text { mature milk production. }\end{array}$ & $\begin{array}{l}\text { Human (Homo } \\
\text { sapiens) }\end{array}$ & $\begin{array}{l}\text { Illumina HiSeq 2000, } 20 \text { million } 100 \\
\text { bp paired-end reads per sample }\end{array}$ & GSE45669 (GEO) & $\begin{array}{l}\text { Lemay and Ballard, } \\
\text { et al. [38] }\end{array}$ \\
\hline $\begin{array}{l}\text { Cellular miRNA profile of human milk } \\
\text { collected before and after feeding. }\end{array}$ & $\begin{array}{l}\text { Human (Homo } \\
\text { sapiens) }\end{array}$ & $\begin{array}{l}\text { Illumina HiSeq 2000, 293,932,547 } \\
\text { reads }\end{array}$ & GSE71098 (GEO) & Alsaweed, et al. [31] \\
\hline $\begin{array}{l}\text { Insight into porcine milk exosomal mRNA } \\
\text { and proteins. }\end{array}$ & $\begin{array}{l}\text { Pig (Sus scrofa) } \\
\text { Landrace }\end{array}$ & $\begin{array}{l}\text { Illumina HiSeq 2000, single-end } \\
\text { sequence reads }\end{array}$ & SSR3436404 (SRA) & Chen Ting, et al. [32] \\
\hline $\begin{array}{l}\text { Assessment of suitability of lactating } \\
\text { rhesus macaques as a model for lactating } \\
\text { humans. }\end{array}$ & $\begin{array}{l}\text { Rhesus macaque } \\
\text { (Macaca mulatta) }\end{array}$ & $\begin{array}{l}\text { Illumina HiSeq 2000, } 100 \mathrm{bp} \text { sin- } \\
\text { gle-end sequence reads }\end{array}$ & GSE49765 (GEO) & Lemay, et al. [37] \\
\hline $\begin{array}{l}\text { Effect of high-fat diet on secreted milk } \\
\text { composition. }\end{array}$ & $\begin{array}{l}\text { Mouse (Mus mus- } \\
\text { culus) }\end{array}$ & Illumina HiSeq 2000 & SRP109609 (SRA) & Chen, et al. [33] \\
\hline $\begin{array}{l}\text { Transcriptome profiling of the sheep } \\
\text { lactating mammary gland. }\end{array}$ & Sheep (Ovis aries) & $\begin{array}{l}\text { Illumina HiSeq } 2000 \text { sequencer, } \\
\text { between } 35-45 \text { million } 75 \mathrm{bp} \\
\text { paired-end reads }\end{array}$ & GSE74825 (GEO) & $\begin{array}{l}\text { Suárez Vega Aroa, et } \\
\text { al. [40] }\end{array}$ \\
\hline $\begin{array}{l}\text { Diet induced differences in milk compo- } \\
\text { sition. Transcriptome of milk from dairy } \\
\text { ewes at } 90 \text { day of lactation and after } \\
3 \text { weeks of diet supplementation with } \\
\text { extruded linseed. }\end{array}$ & $\begin{array}{l}\text { Sheep (Ovis aries) } \\
\text { Comisana breed }\end{array}$ & Illumina HiSeq 2000 & GSE89163 (GEO) & $\begin{array}{l}\text { Giordani Tommaso, } \\
\text { et al. [35] }\end{array}$ \\
\hline $\begin{array}{l}\text { The identification of immune genes in the } \\
\text { milk transcriptome of the Tasmanian devil. }\end{array}$ & $\begin{array}{l}\text { Tasmanian devil } \\
\text { (Sarcophilus har- } \\
\quad \text { risii) }\end{array}$ & $\begin{array}{l}\text { Illumina HiSeq 2000, } 22.5 \text { million } \\
100 \text { bp paired-end reads }\end{array}$ & $\begin{array}{l}\text { PRJNA274196 } \\
\text { (BioProject) }\end{array}$ & $\begin{array}{l}\text { Hewavisenti Rehana } \\
\quad \text { V, et al. [36] }\end{array}$ \\
\hline
\end{tabular}

Major steps in an RNA-Seq study are experimental design, quality control, alignment of reads, genes and transcripts level quantification, visualization, differential gene expression, alternative splicing, functional analysis, gene fusion detection and eQTL mapping [18]. Millions of short reads are the starting point of RNA-Seq bioinformatics analysis. Quality control (QC) of raw sequencing data is essential step in RNA-Seq data analysis. Parameters of raw sequencing data examined by QC tools are total number of reads sequenced, GC content and the overall base quality score. Data that pass raw read data $\mathrm{QC}$ is then aligned to the reference genome or transcriptome. Accurate transcript identification depends on the availability of a high quality assembly of the reference genome.

\section{Milk Transcriptome Profile depends on Different Cell}

\section{Types}

Milk contains somatic cells, which are one of the important defence mechanisms against intramammary infections [19] and their count serves as an indicator of milk quality and intramammary infections. The somatic cell fraction in milk is composed of mammary epithelial cells (MECs) and immune cells - leukocytes [20]. Immune cells represent the major part of milk somatic cells, whereas exfoliated MECs usually represent only several percent of the bulk somatic cell fraction [21]. The most abundant immune cells in normal bovine milk are macrophages, followed by polymorphonuclear (PMN) cells (neutrophils), and lymphocytes [22]. In mastitic milk the proportion of PMNs has been shown to increase (up to 90\%) [23].

Therefore, not only the total count of somatic cells is important, but also the differential cell count, which could be used for assessment of mammary health status [21]. Somatic cells are a heterogeneous mixture of cells and it has been shown that approximately $70 \%$ of the annotated bovine genes are expressed in bovine milk somatic cells [24]. Sequencing of the single cell transcriptomes of cells circulating in milk, would eventually enable transcriptome-based discrimination between different somatic cell types. Changes in milk transcriptome profiles can be correlated with mammary infections, lactation stage, and different mammary traits. For example, expression profiling in milk somatic cells has been used to study mammary gland response to infection [25]. Additionally, biology of lactation was studied by following changes in bovine lactome extracted from milk samples from animals in different lactation stages [24].

\section{Transcriptome Association with Lactation Parameters}

In addition to molecular markers used in marker assisted selection schemes, the transcriptomic studies offer new opportunity for identification of novel candidate genes related to lactation traits in dairy species. Transcriptomic approach revealed more than 33,000 SNPs associated with lactation traits in dairy cows. The analysis of gene expression levels during lactation identified 31 differentially expressed genes between extremely high and low milk protein and fat producing Holstein cows. Among them were parathyroid hormone-like hormone, ribosomal protein L23a, serum amyloid A, tribbles homolog 3 and vascular endothelial growth factor $\mathrm{A}$ as potential candidates for regulation of protein and fat percentage in milk.

Transcriptomic studies in Holstein dairy cows detected expression of genes, which are required for the synthesis and secretion of milk [26]. Based on mammary expression profiles the researchers concluded that at the beginning of lactation the most important functions of the mammary gland are milk synthesis and 
inhibition of cell proliferation [27]. During the course of lactation insulin induced gene 1, peroxisome proliferator-activated receptor (PPAR) and PPAR coactivator 1 are involved in regulation of lipid synthesis, whereas insulin is involved in regulation of protein synthesis [28]. An important result of transcriptomic studies is detection of expression of a wide range of miRNAs during lactation in dairy cows [29]. In the bovine mammary gland, 884 unique miRNA sequences were found and 56 of them were differentially expressed between lactating and non-lactating mammary glands. Upregulated genes in lactating mammary gland are associated with various macromolecular metabolic processes and increased metabolic activity of mammary gland cells during lactation [3038].

\section{Conclusion}

Transcriptomic analysis allows complex, tissue specific analysis of gene expression during different stages of lactation. Differences in the transcriptome in different cell types, different stages of lactation and at different production levels allow identification of genes, which are up- or downregulated in different physiological situations. Selection of biological material for transcriptomic analysis of lactation offers a good opportunity to decipher transcriptome of different cell types in lactating mammary gland [39-41]. In addition to detection of transcribed genomic regions and quantification of allele specific transcripts, transcriptomic analysis also allows identification of post-transcriptional changes and detection of non-protein coding transcripts (miRNA, siRNA, IncRNA,...) which can play an important role in regulation of gene expression in the mammary gland. In combination with SNP analysis and exploitation of QTL data represents RNA-Seq a promising approach for identification of novel informative SNP markers for marker assisted selection.

\section{Acknowledgement}

The research was conducted in the frame of the projects Genetic background of mastitis resistance (J4-7328) and Comparative genomics and genomic biodiversity (P4-0220) funded by Slovenian Research Agency.

\section{References}

1. Selvaggi M, Laudadio V, Dario C, Tufarelli V (2014) Investigating the genetic polymorphism of sheep milk proteins: a useful tool for dairy production. J Sci Food Agric 94(15): 3090-3099.

2. Suárez Vega Aroa, Beatriz Gutiérrez-Gil, Christophe Klopp, Gwenola Tosser-Klopp, Juan José Arranz (2017) Variant discovery in the sheep milk transcriptome using RNA sequencing. BMC Genomics 18(1): 170.

3. Wang Z, Gerstein M, Snyder M (2009) RNA-Seq: a revolutionary tool for transcriptomics. Nat Rev Genet 10(1): 57-63.

4. Hudson Nicholas J, Brian P Dalrymple, Antonio Reverter (2012) Beyond differential expression: the quest for causal mutations and effector molecules. BMC Genomics 13(1): 356.

5. Peschansky VJ, Wahlestedt C (2014) Non-coding RNAs as direct and indirect modulators of epigenetic regulation. Epigenetics 9(1): 3-12.

6. Andersson Leif, Alan L Archibald, Cynthia D Bottema, Rudiger Brauning, Shane C Burgess, et al. (2015) Coordinated international action to accelerate genome-to-phenome with FAANG, the Functional Annotation of Animal Genomes project. Genome Biology 16(1): 57.
7. Martin JA, Wang Z (2011) Next-generation transcriptome assembly. Nat Rev Genet 12(10): 671-682.

8. Divari S, Starvaggi Cucuzza L, Riondato F, Pregel P, Sacchi P, et al. (2018) A two-step immunomagnetic separation of somatic cell subpopulations for a gene expression profile study in bovine milk. J Dairy Res 85(3): 281-287.

9. Cánovas Angela, Gonzalo Rincon, Alma Islas-Trejo, Saumya Wickramasinghe, Juan F Medrano (2010) SNP discovery in the bovine milk transcriptome using RNA-Seq technology. Mammalian genome: official journal of the International Mammalian Genome Society 21(1112): 592-598.

10. Cui Xiaogang, Yali Hou, Shaohua Yang, Yan Xie, Shengli Zhang, et al. (2014) Transcriptional profiling of mammary gland in Holstein cows with extremely different milk protein and fat percentage using RNA sequencing. BMC Genomics 15(1): 226.

11. Casey Theresa, Heather Dover, James Liesman, Lindsey DeVries, Matti Kiupel, et al. (2011) Transcriptome Analysis of Epithelial and Stromal Contributions to Mammogenesis in Three Week Prepartum Cows. Plosone 6(7): e22541.

12. Gao Yuanyuan, Xueyan Lin, Kerong Shi, Zhengui Yan, Zhonghua Wang (2013) Bovine Mammary Gene Expression Profiling during the Onset of Lactation. Plosone 8(8): e70393.

13. Wickramasinghe Saumya, Serenus Hua, Gonzalo Rincon, Alma IslasTrejo, Bruce German J, et al. (2011) Transcriptome Profiling of Bovine Milk Oligosaccharide Metabolism Genes Using RNA-Sequencing. Plosone 6(4): e18895.

14. Piantoni P, Wang P, Drackley JK, Hurley WL, Loor JJ (2010) Expression of metabolic, tissue remodeling, oxidative stress, and inflammatory pathways in mammary tissue during involution in lactating dairy cows. Bioinform Biol Insights 4: 85-97.

15. Valour D, Michot P, Eozenou C, Lefebvre R, Bonnet A, et al. (2015) Dairy cattle reproduction is a tightly regulated genetic process: Highlights on genes, pathways, and biological processes. Animal Frontiers 5(1): 3241.

16. Lowe R, Shirley N, Bleackley M, Dolan S, Shafee T (2017) Transcriptomics technologies. PLoS Comput Biol 13(5): e1005457.

17. Maningat PD, Sen P, Rijnkels M, Sunehag AL, Hadsell DL, et al. (2009) Gene expression in the human mammary epithelium during lactation: the milk fat globule transcriptome. Physiol Genomics 37(1): 12-22.

18. Conesa Ana, Pedro Madrigal, Sonia Tarazona, David Gomez-Cabrero, Alejandra Cervera, et al. (2016) A survey of best practices for RNA-seq data analysis. Genome biology 17: 13-13.

19. Sharma N, Singh NK, Bhadwal MS (2011) Relationship of Somatic Cell Count and Mastitis: An Overview. Asian-Australas J Anim Sci 24(3): 429-438.

20. Alhussien, Mohanned Naif, Ajay Kumar Dang (2018) Milk somatic cells, factors influencing their release, prospects, and practical utility in dairy animals: An overview. Veterinary world 11(5): 562-577.

21. Pillai SR, E. Kunze LM, Sordillo, Jayarao BM (2001) Application of differential inflammatory cell count as a tool to monitor udder health. J Dairy Sci 84(6): 1413-1420.

22. Li N, Richoux R, Boutinaud M, Martin P, Gagnaire V (2014) Role of somatic cells on dairy processes and products: a review. Dairy science \& technology 94(6): 517-538.

23. Kehrli ME, Shuster DE (1994) Factors affecting milk somatic cells and their role in health of the bovine mammary gland. J Dairy Sci 77(2): 619-627.

24. Wickramasinghe Saumya, Gonzalo Rincon, Alma Islas-Trejo, Juan F Medrano (2012) Transcriptional profiling of bovine milk using RNA sequencing. BMC genomics 13: 45-45. 
25. Cremonesi Paola, Rossana Capoferri, Giuliano Pisoni, Marcello De Corvo, Francesco Strozzi, et al. (2012) Response of the goat mammary gland to infection with Staphylococcus aureus revealed by gene expression profiling in milk somatic and white blood cells. BMC Genomics 13(1): 540.

26. Bionaz M, Periasamy K, Rodriguez-Zas SL, Hurley WL, Loor JJ (2012) A novel dynamic impact approach (DIA) for functional analysis of time-course omics studies: validation using the bovine mammary transcriptome. Plosone 7(3): e32455.

27. Finucane KA, McFadden TB, Bond JP, Kennelly JJ, Zhao FQ (2008) Onset of lactation in the bovine mammary gland: gene expression profiling indicates a strong inhibition of gene expression in cell proliferation. Funct Integr Genomics 8(3): 251-264.

28. Bionaz Massimo, Juan J Loor (2011) Gene networks driving bovine mammary protein synthesis during the lactation cycle. Bioinformatics and biology insights 5: 83-98.

29. Li Zhen, Hongyun Liu, Xiaolu Jin, Lijan Lo, Jianxin Liu (2012) Expression profiles of microRNAs from lactating and non-lactating bovine mammary glands and identification of miRNA related to lactation. BMC Genomics 13(1): 731.

30. Dai WT, Zou, YX, White RR, Liu JX, Liu HY (2018) Transcriptomic profiles of the bovine mammary gland during lactation and the dry period. Funct Integr Genomics 18(2): 125-140.

31. Alsaweed Mohammed, Ching Tat Lai, Peter E Hartmann, Donna T Geddes, Foteini Kakulas (2016) Human Milk Cells Contain Numerous miRNAs that May Change with Milk Removal and Regulate Multiple Physiological Processes. International journal of molecular sciences 17(6): 956

32. Chen Ting, Qian-Yun Xi, Jia-Jie Sun, Rui-Song Ye, Xiao Cheng, et al (2017) Revelation of mRNAs and proteins in porcine milk exosomes by transcriptomic and proteomic analysis. BMC veterinary research 13(1):101.
33. Chen Y, Wang J, Yang S, Utturkar S, Crodian J, et al. (2017) Effect of high-fat diet on secreted milk transcriptome in midlactation mice. Physiological Genomics 49(12): 747-762.

34. Crisà Alessandra, Fabrizio Ferrè, Giovanni Chillemi, Bianca Moioli (2016) RNA-Sequencing for profiling goat milk transcriptome in colostrum and mature milk. BMC veterinary research 12(1): 264

35. Giordani Tommaso, Alberto Vangelisti, Giuseppe Conte, Andrea Serra, Lucia Natali, et al. (2017) Transcript profiling in the milk of dairy ewes fed extruded linseed. Genomics Data 11: 17-19.

36. Hewavisenti Rehana V, Katrina M Morris, Denis O’Meally, Yuanyuan Cheng, Anthony T Papenfuss, et al. (2016) The identification of immune genes in the milk transcriptome of the Tasmanian devil (Sarcophilus harrisii). PeerJ 4: e1569-e1569.

37. Lemay Danielle G, Olivia A Ballard, Maria A Hughes, Ardythe L Morrow Nelson D Horseman, et al. (2013) RNA Sequencing of the Human Milk Fat Layer Transcriptome Reveals Distinct Gene Expression Profiles at Three Stages of Lactation. Plosone 8(7): e67531.

38. Lemay Danielle G, Russell C Hovey, Stella R Hartono, Katie Hinde, Jennifer T Smilowitz, et al. (2013) Sequencing the transcriptome of milk production: milk trumps mammary tissue. BMC Genomics 14(1): 872

39. Sun J, Aswath K, Schroeder SG, Lippolis JD, Reinhardt TA, et al. (2015) MicroRNA expression profiles of bovine milk exosomes in response to Staphylococcus aureus infection. BMC Genomics 16: 806.

40. Suárez-Vega, Aroa, Beatriz Gutiérrez-Gil, Christophe Klopp, Gwenola Tosser-Klopp, Juan-José Arranz (2016) Comprehensive RNA-Seq profiling to evaluate lactating sheep mammary gland transcriptome. Scientific Data 3: 160051.

41. Yang Jie, Jicai Jiang, Xuan Liu, Haifei Wang, Gang Guo, et al. (2016) Differential expression of genes in milk of dairy cattle during lactation. Animal genetics 47(2): 174-180.

Your next submission with Juniper Publishers
will reach you the below assets
- Quality Editorial service
- Swift Peer Review
- Reprints availability
- E-prints Service
- Manuscript Podcast for convenient understanding
- Global attainment for your research
- Manuscript accessibility in different formats
( Pdf, E-pub, Full Text, Audio)
- Unceasing customer service
Track the below URL for one-step submission
https://juniperpublishers.com/online-submission.php

